\title{
Berry Fruits Grown in Duzce and Its Neighborhood: Their Medical Applications
}

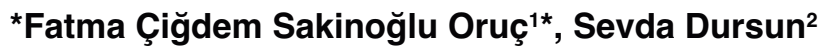 \\ ${ }^{1}$ Fatma Çiğdem SAKINOĞLU ORUÇ (Technical Programs Depertment, Duzce University Cilimli Vodication School, Duzce, TURKEY. \\ ${ }^{2}$ Sevda Dursun(Technical Programs Depertment, Duzce University Cilimli Vodication School, Duzce, TURKEY.
}

\begin{abstract}
Berry fruits possess many positive effects on human health because of their phytochemical contents like phenolic compounds, antioxidants and anthocyanins, and they have also an important place among the functional foods. From the varieties of Isabella grape and Bursa-2 blackberry cultivated in Duzce and its neighborhood, aging-retardant cream, vinegar (cyme) which aids in the weight loss and alleviates the stomach discomfort, and grape and blackberry juice are produced. Besides, other berry fruits are also used but only in the form of folk medicine. Thus, further studies about the berry fruits grown in the region may increase the potential medical usages of those plants.
\end{abstract}

Keywords: Duzce, Berry Fruits, Bursa-2, Phenolic Compounds, Medical Usage.

\section{INTRODUCTION}

Duzce Province, except coastal district of Akcakoca, consists of the concave areas surrounded by the mountains. It extends to the Akcakoca Mountains in the north, the Bolu Mountains in the east, and the western extensions of the Abant Mountains in the southeastern and southern regions. Province is located at an altitude of $150 \mathrm{~m}$ and it is under the influence of humid and mild climate which governs in the coastal areas of the Black Sea Region. In province, annual average temperature is $13.3^{\circ} \mathrm{C}$, average annual precipitation is $822.6 \mathrm{~kg} / \mathrm{m} 2$ and average relative humidity is $75.2 \%$. Duzce is considered to be a rich province in terms of its natural vegetation. ${ }^{1}$ The geographical structure of the region is suitable to grow the berry fruits without irrigation, and berry fruits are cultivated both in wild and cultured conditions. The ellagic acid (anticarcinogen) from phenols, and anthocyanins, quercetin, kaempferol and myricetin from flavones and flavonoids (antioxidant), which are intensively found in the berry fruits, are the most important herbal compounds with "nutraceutical" or "functional food" values. ${ }^{2,3,4}$
In light of above-knowledge, cultivation of berry fruits in Duzce Province and its neighborhood, and their usage for medical purposes are still an undergoing research process.

\section{RESULTS AND DISCUSSION}

According to TURKSTAT data (2013), total agricultural land cultivated in Duzce Province and its neighborhood is about 11231 hectares, of which $25.4 \%$ comprise the fruits. From 65892 tons of fruits produced per year, 176 tons belong to the grapes, and 56 tons belong to the blackberries, figs and raspberries. ${ }^{5}$ Blackberry and black grape cultivated in the region are from the industrialized fruits due to their phenolic compounds, and easy storage and transportation advantages. Blackberry (Rubus canescens DC. var. canescens) plant contains the malic acid, lactic methyl salicylate, tannin, pectin, sugar, flavonoids, magnesium, iodine, manganese, and vitamins A, C, E, K, P and PP. In a study conducted by Pehluvan et al. ${ }^{6}$ in fruit of the blackberry plant, 58-100 TE/g ORAC, $83-326$ mg/100g
DOI: 10.5530/ijper.51.3s.43 Correspondence:

Fatma Çiğdem Sakinoğlu Oruç,

Fatma Çiğdem SAKINOĞLU ORUÇ (Technical Programs Depertment, Duzce University Cilimli Vodication School, Duzce, Turkey.

Phone no: 05316398129 E-mail: cigdemsakinoglu@ duzce.edu.tr 
anthocyanin, $3.69 \mathrm{mg} / 100 \mathrm{~g}$ ellagic acid, 0.5-3.5 $\mathrm{mg} / 100 \mathrm{~g}$ quercetin and $0.1-0.3 \mathrm{mg} / 100 \mathrm{~g}$ kaempferol were identified. Ellagic acid was reported to significantly inhibit the cancer development by reducing the oxidative damages on DNA. ${ }^{7}$ Quercetin was reported to have both anticancer and antioxidant properties. Antioxidants such as quercetin and kaempferol can prevent the lipid peroxidation, which causes the cell destruction in human body. ${ }^{2}$

Isabella grape (Vitis labrusca L. Isabella), locally known as black grape, contains the resveratrol (3,5,4-trihydroxystilbene), acids (tartaric, citric, malic, succinic, fumaric, pyruvic, $\alpha$-oxaglutaric, glyceric, glycolic, dimethyl-succinic, shikimic and quinic), vitamins B (B1 and B2), minerals, potassium, magnesium and iron. Invitro and animal studies have demonstrated that resveratrol compound particularly in Isabella grape inhibits the capillary blockage by its antioxidant activity, and hinders the platelet aggregation in capillary vessels via modulation of the apoliprotein and lipid synthesis. ${ }^{8,9}$ It was thereby reported that human body can obtain more benefits from the resveratrol compound when the grape is consumed along with its shells as a whole. ${ }^{10,11}$

Arbutus unedo (strawberry tree) plant has constipating and germicidal effects. Its microbicidal effect is particularly beneficial for the urinary tract infections. Its fruits have also diuretic properties. In region, this plant is mainly consumed as fresh fruits as well as its jam is made.

Ficus carica L. (fig) has widespread consumption among the public because of its anti-constipation property and beneficial effects on the digestive system. It is found almost in every home gardens in the region.

\section{CONCLUSION}

In Turkey, usage of berry fruits for medicinal purposes has been increasing year by year. For this reason, Duzce Province and its neighborhood have been suitable regions for cultivation of berry fruits due to the relevant ecological and geographical conditions. Thus, ongoing researches in the region will provide possibilities for discovery of the novel compounds for alternative medicine. Overall, berry fruits grown in the region seem to have great importance for future in terms of the alternative medicine.

\section{ACKNOWLEDGEMENT}

Nil

\section{CONFLICT OF INTEREST}

Nil

\section{REFERENCES}

1. MeSH Browser [database on the Internet]. Bethesda (MD): [cited 2016 Oct.15]. http:/www.duzce.gov.tr/tarihi-ve-cografi-yapisi

2. Anonymous,. Caneberries are Healthy Fruits. ORBC Nutraceutical Information, Nutraceutical Bulletin Vol. (3): 1, 2002 :www.oregon-berries. com/cx15/nutra2.htm

3. Costantino L, Albasino A, Rastelli G, Benvenuti S. Activity of Polyphenolic Crude Extracts as Scavengers of Superoxide Radicals and Inhibitors of Xanthine Oxidase. Plant Med. 1992;58(04):342-4

4. Heinonen IM, Lehtonen PJ, Hopia Al. Antioxidant Activity of Berry Phenolics on Human Low-density Lipoprotein and Liposome Oxidation. J. Agri. Food Chem. 1998;46(10): 25-31.

5. MeSH Browser [database on the Internet]. Bethesda (MD): TURKSTAT;2013[cited 2014 Oct.15]. Available from: http://www.tuik.gov.tr/UstMenu. do?metod=temelist. Files updated 5 years.

6. Pehluvan $M$, Güleryüz $M$. Ahududu ve böğürtlenin insan sağlığı açısından önemi, BAHÇE. 2004;33(1-2):51-57

7. Nixon D. Oregon Canneberries; What Research is Revealing about Red Raspberries. (www.oregon-berries.com). 2002;20.

8. Meyer AS, Yi OS, Pearson DA, Waterhouse AL, Frankel EN. Inhibition of human low-density lipoprotein oxidation in relation to composition of phenolic antioxidants in grapes (Vitis vinifera). J. Agric. Food. Chem. 1997;45(5):163843.

9. Meyer AS, Jepsen SM, Sorensen NS. Enzymatic release of antioxidants for human low-density lipoprotein from grape pomace. J. Of Agric. Food Chem. 1998;46(7):2439-46.

10. Goldberg DM. Does wine work?. Clin Chem. 1995;41:14-6.

11. Soleas GJ, Diamandis EP, Goldberg DM. Wine as a biological fluid: history, production, and role in disease prevention. J Clin Lab Anal 1. 997;(5):287-313. 


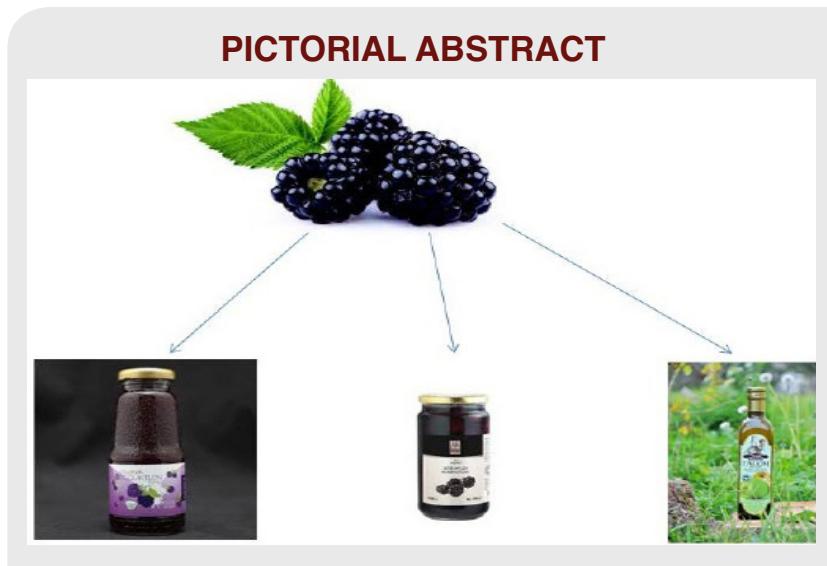

\section{ABOUT AUTHORS}
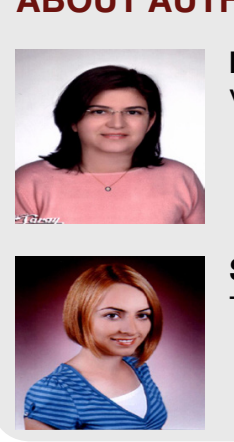

Sevda Dursun: Technical Programs Depertment, Duzce University Cilimli Vodication School, Duzce, TURKEY.

Cite this article: Fatma Oruç ÇS, DURSUN S. Berry Fruits Grown in Duzce and Its Neighborhood: Their Medical Applications. Indian J of Pharmaceutical Education and Research. 2017;51(3)Suppl:S338-340. 